\title{
Prediction of spring ice phenomena on lakes and reservoirs using teleconnection indices
}

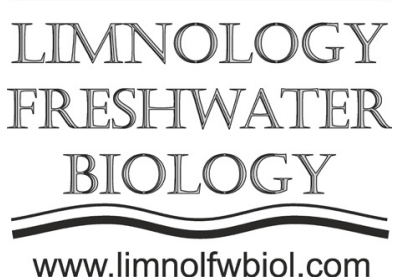

\author{
Sutyrina E.N. \\ Irkutsk State University, Karl Marx Str., 1, Irkutsk, 664003, Russia
}

\begin{abstract}
The investigation is aimed to develop techniques for long-term forecasting the timing of the final disappearance of all ice on Lake Baikal, Krasnoyarsk, Irkutsk, Bratsk and Ust'-Ilimsk reservoirs using teleconnection AO (Arctic Oscillation) index values. The methods suggested by author permit to anticipate a character of the ice situation with the average earliness from 21 to 48 days and the maximum one from 35 to 60 days. The probability of the permissible error value of the proposed predictive dependencies is from 88.9 to $100.0 \%$, their correlation index ranges from 0.89 to 0.93 . The values of the prognostic information coefficient above 0.83 demonstrate the temporal stability and practical use possibility of the obtained predictive techniques. Thus, tests of potency of the developed forecasting techniques show a good quality of predictions of the dates when the South, Central and North basins of Lake Baikal, Krasnoyarsk, Irkutsk, Bratsk and Ust'-Ilimsk reservoirs become totally free of ice.
\end{abstract}

Keywords: Lake Baikal, Angara-Yenisei cascade, final disappearance of all ice, ice forecasts, Arctic Oscillation index.

\section{Introduction}

Lake Baikal and the reservoirs of the AngaraYenisei hydroelectric power plants cascade are located in an area with a sharply continental climate and are covered by ice from four to six month in a year (Verbolov et al., 1965; Donchenko, 1987). These water bodies ice regime is closely related to weather conditions, and therefore the timing of the onset of spring ice phenomena is subject to significant interannual variability, that determines the relevance of issuing ice forecasts. In addition huge inland water bodies ice forecasting are of great practical value for navigation since ice prevents shipping. Thus, the study is concerned with the developing techniques for longterm forecasting the timing of the final disappearance of all ice on Lake Baikal, Krasnoyarsk, Irkutsk, Bratsk and Ust'-Ilimsk reservoirs using teleconnection indices values.

\section{Materials and methods}

The dates of the final disappearance of all ice on the water bodies under investigation were derived from AVHRR (Advanced Very High Resolution Radiometer) and MODIS (Moderate Resolution Imaging Spectroradiometer) data for the period of 1998-2016 with use of author's approach (Sutyrina, 2008). Using this information average and extreme dates when the South, Central and North basins of Lake Baikal, Krasnoyarsk, Irkutsk, Bratsk and Ust'-Ilimsk reservoirs become totally free of ice were estimated during this period. It was established that the timing of the ice disappearance on aquatories of these reservoirs varied widely from year to year with a range of 21-26 days.

The interannual variability of the occurrence of spring ice phenomena in the water bodies under investigation is caused by the fluctuation of large-scale processes in the atmosphere, developing over a long time and occupying a significant space. It was found that the interannual variation of the timing of the final disappearance of all ice on these water bodies were in antiphase with the interannual fluctuations of the values of Arctic Oscillation (AO) index, and this circumstance favored to use this index as suitable predictor for ice forecasts.

\section{Results}

As a result of the research, the regional predictive polinomial relationships bitween satellite-derived dates of the final disappearance of all ice on water bodies under investigation and AO index values, averaged over different time intervals, were developed.

These predictive relationships permit to foresee the spring ice phenomena with the average earliness 
from 21 to 48 days and the maximum one from 35 to 60 days. The values of the probability of the permissible error of the developed predictive dependencies are from 88.9 to $100.0 \%$, their correlation index ranges from 0.89 to 0.93 . The above indicators was calculated based on the initial datasets. Therefore, the temporal stability of the prognostic dependencies was additionally evaluated using the "ejected points" method. The estimated values of the prognostic information coefficient above 0.83 show the temporal stability and possibility of practical use of the obtained predictive techniques.

\section{Conclusions}

The developed predictive methods permit to forecast spring ice phenomena with the average earliness from 21 to 48 days. Tests of potency of the proposed forecasting techniques demonstrate a possibility of their practical use and good quality of predictions of the dates when the South, Central and North basins of Lake Baikal, Krasnoyarsk, Irkutsk, Bratsk and Ust'Ilimsk reservoirs become totally free of ice.

\section{Acknowledgments}

The study was funded by the Russian Foundation of Basic Research, Nos. 17-29-05045, 20-45-380032; 17-29-05047.

\section{References}

Donchenko R.V. 1987. Ledovyy rezhim rek SSSR [Ice regime of rivers of the USSR]. Leningrad: Hydrometeoizdat. (in Russian)

Sutyrina E.N. 2008. Determination of the characteristics of the snow-ice cover on Lake Baikal according to satellite remote sensing data. Materialy Glyatsiologicheskikh Issledovaniy [Glaciological Research Materials] 105: 153-157. (in Russian)

Verbolov V.I., Sokol'nikov V.M., Shimaraev M.N. 1965. Gidrometeorologicheskiy rezhim i teplovoy balans ozera Baikal [The weather conditions and the heat balance of Lake Baikal]. Moscow: Nauka. (in Russian) 